\title{
The carbon footprint of pasture-based milk production: Can white clover make a difference?
}

\author{
M.-J. Yan, ${ }^{*}$ J. Humphreys, $†$ and N. M. Holden* ${ }^{* 1}$ \\ *UCD School of Biosystems Engineering, University College Dublin, Belfield, Dublin 4, Dublin, Ireland \\ †Animal and Grassland Research and Innovation Centre, Teagasc, Moorepark, Fermoy, Co Cork, Ireland
}

\begin{abstract}
Carbon footprint $(\mathrm{CF})$ calculated by life cycle assessment (LCA) was used to compare greenhouse gas emissions from pasture-based milk production relying mainly on (1) fertilizer $\mathrm{N}(\mathrm{FN})$, or (2) white clover (WC). Data were sourced from studies conducted at Solohead Research Farm in Ireland between 2001 and 2006. Ten FN pastures stocked between 2.0 and 2.5 livestock units (LU)/ha with fertilizer $\mathrm{N}$ input between 180 and $353 \mathrm{~kg} /$ ha were compared with $6 \mathrm{WC}$ pastures stocked between 1.75 and $2.2 \mathrm{LU} /$ ha with fertilizer $\mathrm{N}$ input between 80 and $99 \mathrm{~kg} / \mathrm{ha}$. The WC-based system had 11 to $23 \%$ lower CF compared with FN (average $\mathrm{CF}$ was 0.86 to 0.87 and 0.97 to $1.13 \mathrm{~kg}$ of $\mathrm{CO}_{2}$-eq/ $\mathrm{kg}$ of energy-corrected milk, respectively, $91 \%$ economic allocation). Emissions of both $\mathrm{N}_{2} \mathrm{O}$ and $\mathrm{CO}_{2}$ were lower in $\mathrm{WC}$, whereas emissions of $\mathrm{CH}_{4}$ (per $\mathrm{kg}$ of energycorrected milk) were similar in both systems. Ratio sensitivity analysis indicated that the difference was not caused by error due to modeling assumptions. Replacing fertilizer $\mathrm{N}$ by biological nitrogen fixation could lower the CF of pasture-based milk production.
\end{abstract}

Key words: carbon footprint, life cycle assessment, white clover, milk production

\section{INTRODUCTION}

Because of projected population growth and demand for dairy products (Steinfeld et al., 2006), urgent action is needed to achieve a sustainable balance between profitability and the environmental impact of dairy production. The global dairy sector was estimated to contribute $4 \%$ of anthropogenic greenhouse gas (GHG) emissions in 2007 (Gerber et al., 2010). In countries with small human populations and large cattle populations such as Ireland, agriculture is the largest contributor (30.5\% in Ireland) to GHG emissions (Ireland EPA, 2012). As milk production accounts for over one-third

Received July 4, 2012.

Accepted October 19, 2012

${ }^{1}$ Corresponding author: nick.holden@ucd.ie of the output of Irish agricultural commodities (Anonymous, 2011), GHG emissions from milk are important to policy makers. Tools are needed to assist with strategic policy development to enable the dairy sector to thrive while minimizing GHG emissions.

Life cycle assessment (LCA; ISO, 2006) has been developed to assess the environmental impact through the life cycle of products, from the "cradle" (production of raw materials such as iron ore) to the "grave" (the waste management of products after consumption). When applied to agricultural products, attention is often focused on "cradle to farm gate" because the greatest impact is found in the production stage (Schau and Fet, 2007). Because of global concerns about GHG emissions from livestock production, the LCA interpretation of GHG emissions is performed more often than other impact categories (e.g., eutrophication) and is referred to as carbon footprint (CF; O'Brien et al., 2010; Rotz et al., 2010; Flysjö et al., 2011). The main GHG from agriculture are carbon dioxide $\left(\mathrm{CO}_{2}\right)$, methane $\left(\mathrm{CH}_{4}\right)$, and nitrous oxide $\left(\mathrm{N}_{2} \mathrm{O}\right)$. For pasture-based milk production, mineral fertilizer and recycled organic manures are the main $\mathrm{N}$ inputs to grassland and the main sources of $\mathrm{N}_{2} \mathrm{O}$ emissions from farms. Typical management in grazing systems uses mineral fertilizer $\mathrm{N}(\mathbf{F N})$ as the predominant source of $\mathrm{N}$ for grassland (referred to hereafter as FN management) in addition to manure.

In temperate pastures, biological $\mathrm{N}$ fixation (BNF) from forage legumes can also be a significant source of N (10 to $300 \mathrm{~kg}$ of N/ha per year; Ledgard et al., 2009). Because of increasing fertilizer prices and stringent regulation of $\mathrm{N}$ use on farms (European Council, 1991), white clover (Trifolium repens L.) is becoming an increasingly profitable alternative to $\mathrm{FN}$ for pasturebased dairy production (Humphreys et al., 2012). Management of white clover (WC) in grassland (hereafter referred to as WC management) provides BNF, which displaces the need for fertilizer $\mathrm{N}$ and the GHG emissions associated with fertilizer $\mathrm{N}$ in the system. Measurement under field conditions at Solohead Research Farm (Co. Tipperary, Ireland) showed that use of WC reduced $\mathrm{N}_{2} \mathrm{O}$ emissions by $19 \%$ (Li et al., 2011). Stud- 
Table 1. Characteristics of the milk production based on fertilizer N (FN)- and white clover (WC)-based systems at Solohead Research Farm (Co. Tipperary, Ireland) between 2001 and 2006 (Humphreys et al., 2008, 2009) ${ }^{1}$

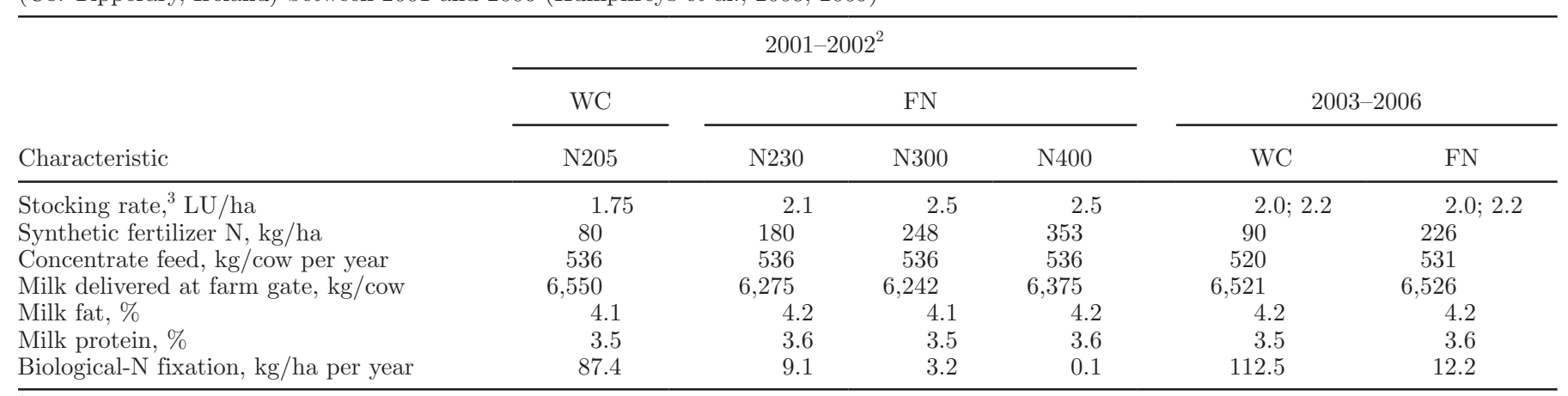

${ }^{1}$ Data are means of 2 and $4 \mathrm{yr}$, respectively.

${ }^{2}$ The acronyms for 2001 and 2002 are consistent with Humphreys et al. (2008); no acronyms were previously defined for the experiments between 2003 and 2006.

${ }^{3}$ The stocking rate (LU = livestock unit) was 2 for 2003 and 2.2 for 2004 to 2006.

ies using model estimates in the Netherlands (Schils et al., 2005) and New Zealand (Basset-Mens et al., 2009) indicated that milk produced from WC has a $\mathrm{CF}$ between 10 and $15 \%$ lower than that from FN. Following from the study of $\mathrm{Li}$ et al. (2011), which was concerned solely with emissions of $\mathrm{N}_{2} \mathrm{O}$ from WC and $\mathrm{FN}$, the objective of the current study was to use LCA to conduct a holistic comparison of WC and FN using data from experimental systems at Solohead Research Farm to determine the difference in GHG emissions, including $\mathrm{CO}_{2}$ and $\mathrm{CH}_{4}$. Specific objectives were to (1) compare the $\mathrm{CF}$ of pasture-based milk production from FN and WC, (2) compare the modeled and measured $\mathrm{N}_{2} \mathrm{O}$ emissions at the same site under similar management conditions, and (3) evaluate the sensitivity of the CF model.

\section{MATERIALS AND METHODS}

The 4 stages of LCA methodology: goal and scope definition, life cycle inventory, life cycle impact assessment, and result interpretation (ISO, 2006), were implemented as follows.

\section{Goal and Scope}

In the goal and scope phase, the production system is described, a functional unit (FU, to which all subsequent inputs and outputs are related) and system boundary (which determines the processes associated with the delivery of the FU) are defined, and in case of multiproduct systems, the allocation procedure between products is specified (ISO, 2006). The goal of the current study was to assess the role of $\mathrm{CF}$ for comparing milk production using $\mathrm{FN}$ and $\mathrm{WC}$ management in low-cost, grass-based, rotational grazing systems. Management data were obtained from experimental systems at Teagasc Solohead Research Farm (52 $51^{\prime}$ N, $08^{\circ} 21^{\prime} \mathrm{W}$ ) between 2001 and 2006 (Table 1; Humphreys et al., 2008, 2009). The first experiment had 4 systems (1 WC and $3 \mathrm{FN}$ ) in 2001 and was replicated in 2002. The second experiment had 2 systems ( $1 \mathrm{WC}$ and 1 FN) in 2003 and was replicated in 2004, 2005, and 2006, resulting in 16 data sets being analyzed for this study. The LCA model was developed in Simapro (PRé Consultants, 2011) and was replicated for each system separately. The FU was defined as $1 \mathrm{~kg}$ of ECM at the farm gate (Sjaunja et al., 1990):

$$
\begin{gathered}
\mathrm{kg} \text { of } \mathrm{ECM}=\mathrm{kg} \text { of milk } \times(0.25+0.122 \\
\times \text { Fat } \%+0.077 \times \text { Protein } \%)
\end{gathered}
$$

where $\mathrm{kg}$ of milk is the total milk delivered from the herd in 1 yr. To account for on-farm consumption by calves, $301 \mathrm{~kg}$ of milk per cow was subtracted from the milk yield each year (O'Mara, 2006).

The system boundary was cradle-to-farm gate, including the foreground processes of milk production on the farm and the background processes of production and transportation of mineral fertilizer; cultivation, processing, and transportation of concentrate feed (except citrus pulp and minerals due to lack of data); production and use of electricity and diesel fuels; and clover seed. Infrastructure (sheds, slurry lagoon, roads), machinery (tractor, milk cooling system), medicines, pesticides, and disposal of plastic for baled silage were not included due to lack of relevance for comparison or because they were shared by both FN and WC management. Bulls were not accounted for because cows were inseminated by AI. Soil carbon sequestration was not included because of a lack of site-specific data, but the effect was considered during the interpretation phase. 
Two parts of the milk CF calculation required allocation: between concentrate feed ingredients and co-products (pre-farm) and between milk and meat (on-farm). Pelletier and Tyedmers (2011) argue that economic allocation is not appropriate because market price does not reflect environmental concerns. However, the concentrate consumption was small (which reflected the practice of average Irish dairy farms) so economic allocation for concentrate feed was used, which is common practice (Yan et al., 2011). Data on sugar and oil co-products (rape meal, palm kernel meal, and molasses) were allocated by Ecoinvent version 2.2 (Ecoinvent, 2011), and soybean hulls and maize gluten meal were derived from Ecoinvent 2.2 data sets (soybeans, at farm; maize starch, at plant) and allocated according to Thomassen et al. (2008) and Cederberg and Mattsson (2000). Allocation between milk and meat (from surplus calves and culled cows) was carried out using an economic method based on market prices between 2000 and 2006 (http://www.cso.ie/px/pxeirestat/Database/ eirestat/AgriculturalInputandOutputAbsolutePrices/ AgriculturalInputandOutputAbsolutePricesstatbank. asp?SP = AgriculturalInputandOutputAbsolutePrices\& Planguage $=0 ;$ http: / / epp.eurostat.ec.europa.eu/portal/ page/portal/agriculture/data/database). The effect of allocation between milk and meat was considered during the interpretation phase.

\section{Life Cycle Inventory}

In the life cycle inventory phase, all input and output processes are defined and quantified (ISO, 2006). The GHG inventory was made by multiplying life cycle activity data by emission factors (EF) derived from the literature (Table 2), and all emissions were calculated on a calendar year basis. Enteric $\mathrm{CH}_{4}$ from cows was determined by estimating net energy (NE) for maintenance, lactation, and pregnancy (Shalloo et al., 2004; O'Mara, 2006). The NE of grazed pasture was calculated as the difference between NE intake from silage and concentrate and that needed to meet total NE requirements (Humphreys et al., 2008). The NE of feed was converted into DMI and multiplied by the $\mathrm{EF}$ for enteric fermentation of $21.6 \mathrm{~g}$ of $\mathrm{CH}_{4}$ per $\mathrm{kg}$ of DMI (O'Mara, 2006). Replacement animals (calves and heifers) were not part of the systems (Humphreys et al., 2008,2009 ) but would be necessary for the dairy unit to function. An average replacement rate of $23 \%$, which was the average replacement rate on the farm during the period, was used to calculate the number of replacement units ( 1 calf and 1 heifer calving at 24 mo of age) in each system. Enteric $\mathrm{CH}_{4}$ from replacement animals was estimated using national average EF (McGettigan et al., 2010). Emissions of $\mathrm{CH}_{4}$ from manure manage- ment were estimated by Intergovernmental Panel on Climate Change (IPCC) Tier 2 methods (McGettigan et al., 2010). Emissions of $\mathrm{CH}_{4}$ from excreta deposition was estimated by multiplying EF for excreta deposition in the field with outdoor days. Emissions of $\mathrm{CH}_{4}$ from slurry storage were added up from each storage period. Farmyard manure (FYM) consisted of manure and rejected silage $(\sim 93 \mathrm{~kg} /$ cow per year) and was land spread after about $180 \mathrm{~d}$ of storage. Emissions of $\mathrm{CH}_{4}$ from FYM storage were estimated by multiplying EF by days stored and volume.

Direct $\mathrm{N}_{2} \mathrm{O}$ emissions from manure management and soils were estimated using the methodology of McGettigan et al. (2010; Table 2). Excretion of $\mathrm{N}$ was estimated as the difference between intake of $\mathrm{N}$ and $\mathrm{N}$ deposited in milk, in calves, or in BW change of the cows (Humphreys et al., 2008). The $\mathrm{N}$ excretion of replacement animals were estimated as proportionate to dairy cow according to Statutory Instrument No. 610 (European Communities, 2010, p 38-39). About 36\% of the $\mathrm{N}$ was excreted during the housing period (including milking time), $94 \%$ of which was assumed to be stored as slurry, whereas the rest went into FYM (McGettigan et al., 2010). After excluding $\mathrm{NH}_{3}$ and $\mathrm{NO}_{\mathrm{x}}$ volatilization according to McGettigan et al. (2010), the remainder of the $\mathrm{N}$ was multiplied by relevant $\mathrm{EF}$ to obtain the direct $\mathrm{N}_{2} \mathrm{O}$ emissions on farm (Table 2).

Indirect $\mathrm{N}_{2} \mathrm{O}$ emissions from $\mathrm{NH}_{3}$ deposition and leaching were estimated using IPCC Tier 2 methods (McGettigan et al., 2010). Diesel combustion due to on-farm fieldwork was estimated from Kramer et al. (1999). Emissions of $\mathrm{CH}_{4}$ and $\mathrm{N}_{2} \mathrm{O}$ from the concrete yard were excluded because of their very small contributions (Casey and Holden, 2005). No appropriate EF were found for $\mathrm{CH}_{4}$ or $\mathrm{N}_{2} \mathrm{O}$ emission from dirty water storage and spreading, so they were not included.

Emission factors for background data (except electricity production) were taken from Ecoinvent v. 2.2 (Ecoinvent, 2011). Data sets for GHG emissions from production of calcium ammonium nitrate $(\mathbf{C A N})$ and urea were selected because they were the 2 types of $\mathrm{N}$ fertilizers used on the research farm. A standard concentrate formulation was obtained from feed suppliers, and data sets regarding producing and processing relevant ingredients were selected from Ecoinvent v. 2.2 (Ecoinvent, 2011) to calculate the GHG emissions (including that from land use change). Electricity use in the systems was estimated from whole-farm records (in $\mathrm{kWh}$, deducting that for office use and other equipment) and proportioned by the number of dairy cows because electricity is mainly used for milking and cooling of milk. Emissions associated with electricity use in each system were taken from Irish energy reports as the average of 2001 to $2006\left(0.68 \mathrm{~kg}\right.$ of $\mathrm{CO}_{2}$-eq/ 
Table 2. On-farm emission factors used in the modeling for fertilizer N (FN)- and white clover (WC)-based systems

\begin{tabular}{|c|c|c|c|}
\hline Item & $\mathrm{CO}_{2}$ & $\mathrm{CH}_{4}$ & $\mathrm{~N}_{2} \mathrm{O}$ \\
\hline \multicolumn{4}{|l|}{ Enteric fermentation } \\
\hline Dairy cows ${ }^{1}$ & & $21.6 \mathrm{~g} / \mathrm{kg}$ of DMI & \\
\hline $0-1 \mathrm{yr}^{2}$ & & $27.79 \mathrm{~kg} /$ (head, yr) & \\
\hline \multicolumn{4}{|l|}{ Manure management } \\
\hline Slurry storage $e^{2,3}$ & & $0.0082 \mathrm{~kg} /\left(\mathrm{m}^{3}, \mathrm{~d}\right)$ & $0.001 \mathrm{~kg}$ of $\mathrm{N}_{2} \mathrm{O}-\mathrm{N} /\left(\mathrm{kg}\right.$ of $\mathrm{N}_{\text {excreted in slurry }}-\mathrm{kg}$ of $\left.\mathrm{NH}_{3}-\mathrm{N}\right)$ \\
\hline Farmyard manure (FYM) storage ${ }^{2,3}$ & & $0.0059 \mathrm{~kg} /\left(\mathrm{m}^{3}, \mathrm{~d}\right)$ & $\begin{array}{l}0.02 \mathrm{~kg} \text { of } \mathrm{N} /\left(\mathrm{kg} \text { of } \mathrm{N}_{\text {excreted in FYM }}-\mathrm{kg} \text { of } \mathrm{NH}_{3}-\mathrm{N}+\mathrm{kg} \text { of }\right. \\
\left.\mathrm{N}_{\text {rejected silage }}\right)\end{array}$ \\
\hline Excreta in field ${ }^{2,4}$ & & $0.001683 \mathrm{~kg} /(\mathrm{cow}, \mathrm{d})$ & $0.02 \mathrm{~kg}$ of $\mathrm{N}_{2} \mathrm{O}-\mathrm{N} /\left(\mathrm{kg}\right.$ of $\mathrm{N}_{\text {excreted in field }}-\mathrm{kg}$ of $\left.\mathrm{NH}_{3}-\mathrm{N}\right)$ \\
\hline Slurry spreading ${ }^{2,5}$ & & $0.00007-0.0123 \mathrm{~kg} / \mathrm{m}^{3}$ & $\begin{array}{l}\text { Slurry, FYM, and fertilizer: } 0.0125 \mathrm{~kg} \text { of } \mathrm{N}_{2} \mathrm{O}-\mathrm{N} /(\mathrm{kg} \text { of } \mathrm{N} \\
\left.-\mathrm{kg} \text { of } \mathrm{NH}_{3}-\mathrm{N} \text { and } \mathrm{NO}_{\mathrm{x}}-\mathrm{N}\right)\end{array}$ \\
\hline FYM spreading ${ }^{2,5}$ & & $0.0027 \mathrm{~kg} / \mathrm{kg}$ & \\
\hline Fertilizer spreading ${ }^{2}$ & & & \\
\hline \multicolumn{4}{|l|}{ Indirect $\mathrm{N}_{2} \mathrm{O}$ emission ${ }^{2}$} \\
\hline From $\mathrm{NH}_{3}$ deposition & & & Volatilized $\mathrm{NH}_{3} \times 0.01$ \\
\hline
\end{tabular}

${ }^{1}$ O'Mara (2006).

${ }^{2}$ McGettigan et al. (2010).

${ }^{3}$ Husted (1994).

${ }^{4}$ Jarvis et al. (1995).

${ }^{5}$ Chadwick et al. (2000).

${ }^{6}$ Kramer et al. (1999).

kWh; Howley et al., 2008), which was considered more reliable than the $0.216 \mathrm{~kg}$ of $\mathrm{CO}_{2}$-eq/ $\mathrm{kWh}$ from Ecoinvent v 2.2 (Ecoinvent, 2011). All transportation was assumed to start from origin (fertilizer from Germany, clover seeds from Denmark and New Zealand, and concentrates from various places) and as necessary through Rotterdam and inland shipping to Dublin, Ireland, and then to the research farm.

\section{Life Cycle Impact Assessment}

In the life cycle impact assessment stage, the inventory is linked to specific environmental impact categories and indicators (ISO, 2006). To express the impact of GHG emissions, a commonly used indicator is global warming potential (GWP) defined for a period of 100 years. The mid-point method IPCC 2007 GWP 100a v 1.02 (developed by the IPCC; Forster et al., 2007) was selected in Simapro (PRé Consultants, 2011), which defined the GWP of $\mathrm{CO}_{2}$ as 1 , that of $\mathrm{CH}_{4}$ as 25, and that of $\mathrm{N}_{2} \mathrm{O}$ as 298. The total emissions of GHG were determined as follows:

$$
\mathrm{GHG}=\Sigma \mathrm{GWP}_{\mathrm{i}} \times \mathrm{m}_{\mathrm{i}},
$$

where $\mathrm{m}_{\mathrm{i}}$ is the mass $(\mathrm{kg})$ of the emitted gas $\mathrm{i}$, where $\mathrm{i}$ refers to $\mathrm{CO}_{2}, \mathrm{CH}_{4}$, or $\mathrm{N}_{2} \mathrm{O}$. Finally, $\mathrm{CF}$ was calculated using the GHG allocated to milk production:

$$
\mathrm{CF}=\mathrm{GHG} \text { allocated to milk production/FU. }
$$

\section{Interpretation}

Interpretation of the life cycle impact assessment consists of identifying significant issues, evaluating sensitivity, and drawing conclusions (ISO, 2006). The $\mathrm{CF}$ of milk production from WC and FN throughout the $6 \mathrm{yr}$ was compared using the $t$-test. Geographical origin of emissions (i.e., within or outside Ireland) and major components of $\mathrm{CO}_{2}, \mathrm{CH}_{4}$, and $\mathrm{N}_{2} \mathrm{O}$ emissions were identified. Modeled $\mathrm{N}_{2} \mathrm{O}$ emissions were compared with measurement at Solohead under similar stocking rate and fertilizer $\mathrm{N}$. The relationship between surplus $\mathrm{N}$ (including clover BNF; Humphreys et al., 2008) and $\mathrm{CF}$ was studied. Because of the linear characteristic of the $\mathrm{CF}$ model, the main contributors (accounting for $95 \%$ of the GHG) had large influences and thus the relevant assumptions and parameters were evaluated by assessing their tenability with ratio sensitivity analysis (Björklund, 2002). Ratios were calculated by determining the percentage that those assumptions and the EF needed to change to reverse the ranking of $\mathrm{WC}$ and FN with respect to $\mathrm{CF}$. The uncertainty ranges of $\mathrm{EF}$ from the literature were used to gain insight into the tenability of the ratio change. The ratio sensitivity analysis was mainly conducted with $\mathrm{EF}$ rather than activity data because most activities of WC and FN management were the same. Thus, the aim of the ratio sensitivity was primarily to look at the effect of the uncertainty of EF on the comparison between the systems. Comparisons with similar Dutch and New 
Table 3. Process contribution and ratio sensitivity analysis ( $\mathrm{kg}$ of $\mathrm{CO}_{2}$-eq/ $\mathrm{kg}$ of ECM; \% contribution) for the fertilizer $\mathrm{N}$ (FN)- and white clover (WC)-based systems

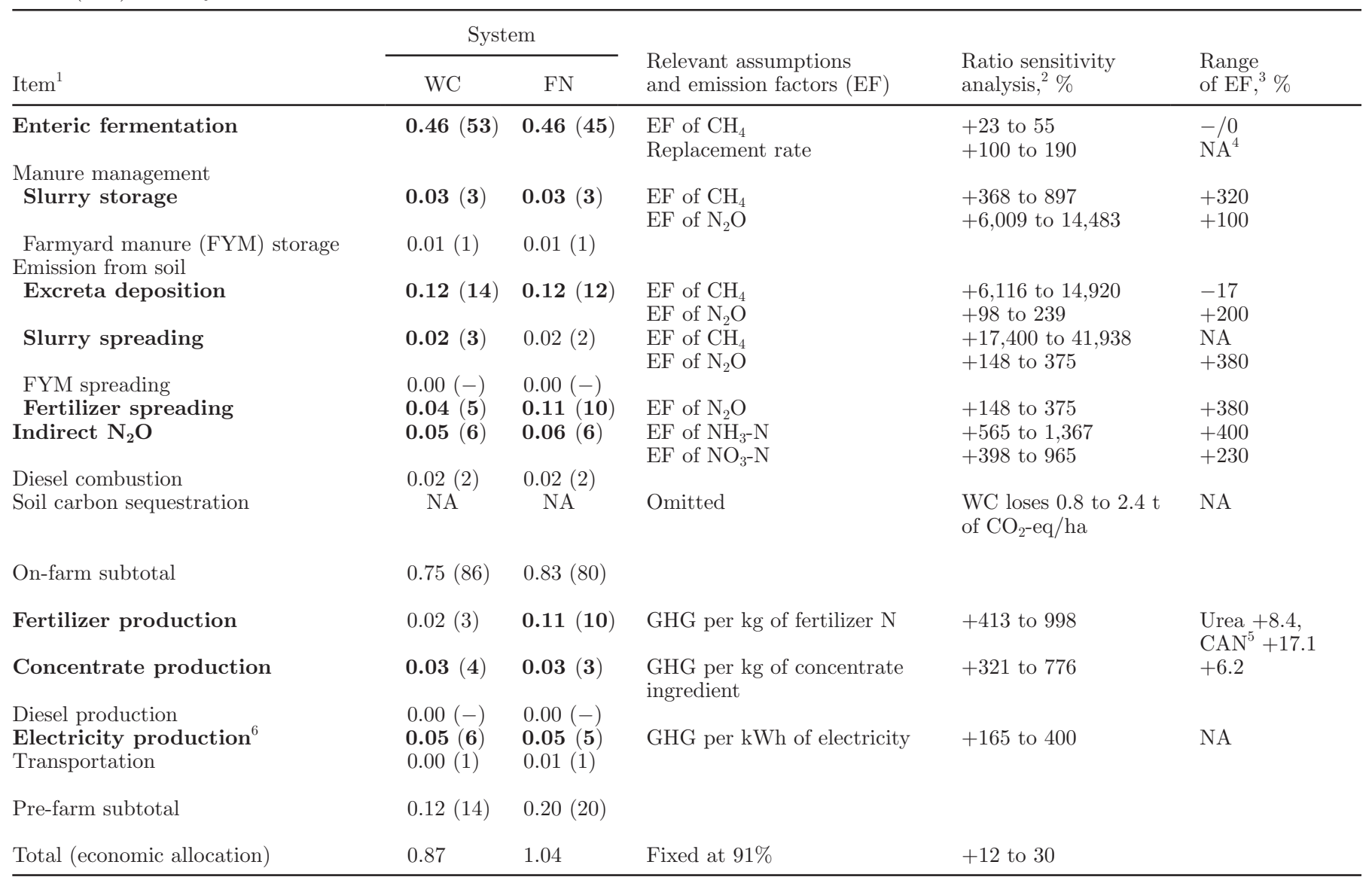

${ }^{1}$ Components that accounted for $95 \%$ of total greenhouse gases (GHG) are shown in bold.

${ }^{2}$ Ratios were calculated by determining the percentage that those assumptions and EF needed to change to reverse the ranking of WC and FN with respect to carbon footprint.

${ }^{3}$ Range of EF suggested by the literature.

${ }^{4} \mathrm{NA}=$ not available.

${ }^{5}$ Calcium ammonium nitrate.

${ }^{6}$ Only refers to the electricity used on farm; that used for production and transportation of fertilizer, concentrate, and diesel was embedded in relevant data sets of Ecoinvent (2011).

Zealand studies were made in terms of methodology and dairy systems.

\section{RESULTS}

\section{Carbon Footprint of WC and FN}

The CF of milk was found to be 11 to $23 \%$ lower on WC compared with FN across the range of fertilizer N inputs. With economic allocation (91\% to milk), the average milk $\mathrm{CF}$ from $\mathrm{WC}$ was 0.86 to $0.87 \mathrm{~kg}$ of $\mathrm{CO}_{2^{-}}$ eq $/ \mathrm{kg}$ of ECM and that from FN was 0.97 to $1.13 \mathrm{~kg}$ of $\mathrm{CO}_{2}$-eq $/ \mathrm{kg}$ of ECM $(P<0.001$; Table 3$)$. A greater proportion of GHG emissions was from within Ireland and was higher from WC (85\%) than from $\mathrm{FN}(80 \%)$.
On average, $\mathrm{CH}_{4}$ emissions contributed 0.49 and 0.50 $\mathrm{kg}$ of $\mathrm{CO}_{2}$-eq $/ \mathrm{kg}$ of ECM to $\mathrm{WC}$ and $\mathrm{FN}(P>0.05)$, the majority of which was from enteric fermentation, followed by manure management, and emissions from soil. Emissions of $\mathrm{N}_{2} \mathrm{O}$ were significantly different between $\mathrm{WC}$ and $\mathrm{FN}\left(0.26\right.$ and $0.39 \mathrm{~kg}$ of $\mathrm{CO}_{2}$-eq $/ \mathrm{kg}$ of ECM, respectively; $P<0.001$ ), the majority of which was from soils and production of concentrate. Because of the larger amount of fertilizer $\mathrm{N}$ applied in $\mathrm{FN}$, a substantially larger share of pre-farm $\mathrm{N}_{2} \mathrm{O}$ emissions was found for $\mathrm{FN}(19 \%)$ than for WC (8\%); the on-farm $\mathrm{N}_{2} \mathrm{O}$ emissions from WC and FN were 9.4 and $14.0 \mathrm{~kg}$ of $\mathrm{N} /$ ha per year, respectively. Likewise, $\mathrm{CO}_{2}$ emissions were significantly different between $\mathrm{WC}$ and $\mathrm{FN}(0.12$ and $0.14 \mathrm{~kg}$ of $\mathrm{CO}_{2}-\mathrm{eq} / \mathrm{kg}$ of ECM; $\left.P<0.001\right)$, most 
of which was from pre-farm production of fertilizer, concentrate, and electricity, and on-farm diesel combustion. Carbon dioxide from land transformation was mainly from palm fruit production for concentrate feed. Significant correlation was found between surplus N per $\mathrm{kg}$ of $\mathrm{ECM}$ and $\mathrm{CF}$ (Figure $1 ; \mathrm{R}^{2}=0.66, P<0.001$ ), which indicated that a 1 -g reduction of on-farm surplus $\mathrm{N}$ could reduce $\mathrm{CF}$ by $23 \mathrm{~g}$ of $\mathrm{CO}_{2}$-eq. From 2003 to 2006, when WC and FN had the same stocking density (2.0 and 2.2 cows/ha), the CF of WC was significantly lower than that of FN (Table 4).

\section{Ratio Sensitivity Analysis of Assumptions and Parameters}

The contributors that accumulated 95\% of GHG (shown in bold in Table 3) were enteric $\mathrm{CH}_{4}$, excreta deposition, fertilizer spreading, fertilizer production, electricity production, indirect $\mathrm{N}_{2} \mathrm{O}$, slurry storage, concentrate production, and slurry spreading.

The largest contributing factor was enteric $\mathrm{CH}_{4}$, which was determined by $\mathrm{EF}$ of enteric $\mathrm{CH}_{4}$ for each type of animal. To reverse the ranking of WC to $\mathrm{FN}$ (while keeping $\mathrm{FN}$ unchanged), the EF of enteric $\mathrm{CH}_{4}$ in WC needed to be increased by 23 to $55 \%$ and the

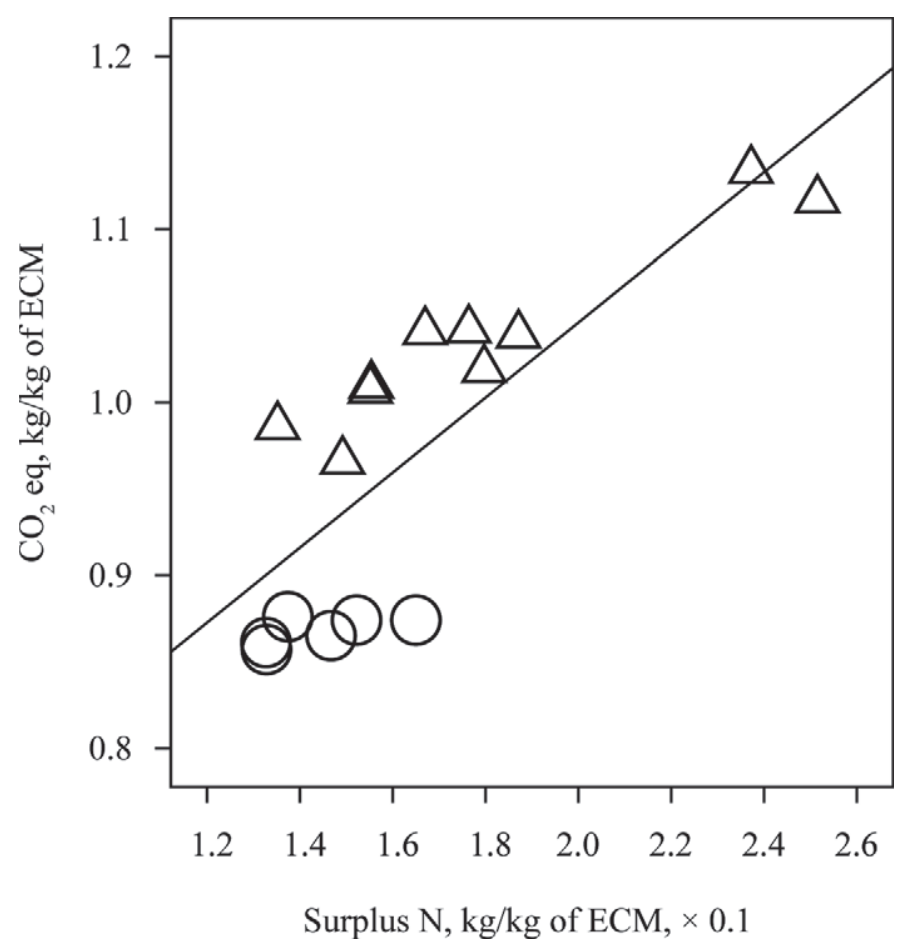

Figure 1. Relationship between on-farm surplus $\mathrm{N}(\mathrm{kg}$ of $\mathrm{N} / \mathrm{kg}$ of $\mathrm{ECM}, \times 0.01)$ and carbon footprint $\left(\mathrm{kg}\right.$ of $\mathrm{CO}_{2}$-eq $/ \mathrm{kg}$ of ECM, economic allocation, $\mathrm{r}=0.6, P<0.001)$ of fertilizer $\mathrm{N}(\mathrm{FN} ; \Delta)$ - and white clover (WC; $\bigcirc$ )-based systems.
Table 4. Carbon footprint (economic allocation between milk and meat) of fertilizer $\mathrm{N}$ (FN)- and white clover (WC)-based systems under relevant stocking rates

\begin{tabular}{llc}
\hline & \multicolumn{2}{c}{$\begin{array}{c}\text { Carbon footprint, } \\
\mathrm{kg} \text { of } \mathrm{CO}_{2} / \mathrm{kg} \text { of ECM }\end{array}$} \\
\cline { 2 - 3 } $\begin{array}{l}\text { Stocking rate, } \\
\text { livestock unit/ha }\end{array}$ & $\mathrm{WC}$ & $\mathrm{FN}$ \\
\hline 1.75 & 0.89 & \\
2.1 & & 1.00 \\
2.0 & $0.88^{\mathrm{a}}$ & $1.05^{\mathrm{b}}$ \\
2.2 & $0.86^{\mathrm{a}}$ & $1.01^{\mathrm{b}}$ \\
2.5 & & $1.07^{1}$ \\
2.5 & & $1.16^{2}$ \\
\hline
\end{tabular}

${ }^{\mathrm{a}, \mathrm{b}}$ Means within a row with different superscripts differ $(P<0.001)$.

${ }^{1}$ Fertilizer $\mathrm{N}$ rate of $248 \mathrm{~kg}$ of $\mathrm{N} / \mathrm{ha}$.

${ }^{2}$ Fertilizer $\mathrm{N}$ rate of $353 \mathrm{~kg}$ of $\mathrm{N} / \mathrm{ha}$.

replacement rate by 100 to $190 \%$ (depending on $\mathrm{N}$ input in FN).

The second largest contributor to $\mathrm{CF}$ was $\mathrm{N}_{2} \mathrm{O}$ from $\mathrm{N}$ deposition on pasture. The third largest contribution was from spreading fertilizer $\mathrm{N}$, which consisted of $\mathrm{N}_{2} \mathrm{O}$ from urea and CAN. To reverse the ranking of $\mathrm{WC}$ and $\mathrm{FN}$, the $\mathrm{EF}$ for $\mathrm{N}_{2} \mathrm{O}$ emissions from $\mathrm{N}$ deposition on pasture in WC needed to be increased by 98 to $239 \%$ (while keeping the $\mathrm{N}$ excretion unchanged), the EF of $\mathrm{CH}_{4}$ from excretion deposition needed to be increased by 6,116 to $14,920 \%$, or the EF for fertilizer spreading needed to be increased by 148 to $375 \%$.

Soil carbon sequestration was not considered and the same allocation factors were used. To reverse the ranking of WC and FN, WC needed to lose 0.8 to $2.4 \mathrm{t}$ of $\mathrm{CO}_{2}$-eq/ha, or the economic allocation factor needed to be increased by 12 to $30 \%$. All other contributors were small, and thus large changes were required for the ratio sensitivity analysis (Table 3) and they were much larger than the uncertainty ranges in the literature.

\section{DISCUSSION}

\section{Comparison with Similar Studies}

A range of annual weather conditions (rainfall from 796 to $1,149 \mathrm{~mm}$ ) and management practices (stocking density from 1.75 to 2.5 cows/ha; fertilizer application rate from 80 to $353 \mathrm{~kg}$ of $\mathrm{N} / \mathrm{ha}$ ) were encompassed by the data sets used in this study. The difference in milk CF between the systems was in general agreement with other similar studies. For example, Schils et al. (2005) found that GHG emissions per kilogram of milk from a grass-clover system were 10\% lower than those from a grass-fertilizer N system. The methodology was similar to that used in the current study although it was referred to as whole-farm accounting. The main differences in the Schils et al. (2005) study were that 
carbon sequestration was $24 \%$ lower in the grass-clover system because of the greater proportion of plowing, and $\mathrm{BNF}$ was included as a source of $\mathrm{N}_{2} \mathrm{O}$ emission (5 $\mathrm{g}$ of $\mathrm{N} / \mathrm{kg}$ of $\mathrm{N}$ fixed), both of which reduced the difference in milk CF between $\mathrm{WC}$ and $\mathrm{FN}$. Recent research has shown that direct $\mathrm{N}_{2} \mathrm{O}$ emission from $\mathrm{BNF}$ per se is thought to be negligible and the $\mathrm{N}_{2} \mathrm{O}$ emissions induced by the growth of legume crops and forages may be estimated solely as a function of the above-ground and below-ground $\mathrm{N}$ inputs from crop residues (Rochette and Janzen, 2005). Basset-Mens et al. (2009) followed the LCA approach and found that $\mathrm{CF}$ from a grassclover system with zero fertilizer $\mathrm{N}$ was $15 \%$ lower than that from a grass-fertilizer N system under $139 \mathrm{~kg}$ of N/ ha per year. Differences existed in their calculation of GHG inventory (e.g., EF for $\mathrm{N}_{2} \mathrm{O}$ emission from excreta deposition was $1 \%$ instead of the $2 \%$ in this study) but should not affect the general conclusion.

In terms of dairy systems, there were large differences between Schils et al. (2005) and Basset-Mens et al. (2009). In Schils et al. (2005), stocking density was 1.9 to 2.2 livestock units/ha of high-yielding HolsteinFriesian cows (about 8,194 kg of milk/cow per year), with a short grazing season (April to September) and high concentrate feeding (approximately 1,823 kg/cow per year). In Basset-Mens et al. (2009), stocking density was high, 2.7 to 5.2 cows/ha of low-yielding HolsteinFriesian cows (approximately 4,845 kg of milk/cow per year), with a long grazing season (almost all year) and zero concentrate feeding. The system in the current study was intermediate in terms of milk output per cow, stocking rate, grazing period, and concentrate fed. Although direct comparison between LCA studies has been difficult (Yan et al., 2011), the 3 studies collectively show that $\mathrm{WC}$ reduces the $\mathrm{CF}$ of milk production under research conditions.

\section{$\mathrm{N}_{2} \mathrm{O}$ Emissions from $W C$ and $\mathrm{FN}$}

The fundamental difference between the CF of milk production from $\mathrm{WC}$ and $\mathrm{FN}$ was the contribution of BNF. During 2004, 2005, and 2006, the WC and FN systems had the same stocking density (2.2 livestock units/ha) and achieved similar milk yields per cow (6,515 and $6,518 \mathrm{~kg} /$ cow per year), and the total $\mathrm{N}$ input from fertilizer, estimated BNF, and animal excretion to soils were 477 and $528 \mathrm{~kg}$ of N/ha, respectively (without excluding $\mathrm{NH}_{3}-\mathrm{N}$ loss during fertilizer spreading and manure storage). The modeled $\mathrm{N}_{2} \mathrm{O}$ emissions were 10.7 and $14.2 \mathrm{~kg}$ of $\mathrm{N} /$ ha per year from $\mathrm{WC}$ and FN swards during these years. In other words, in the present study, WC had $9 \%$ lower total $\mathrm{N}$ inputs but was estimated to have $25 \%$ lower $\mathrm{N}_{2} \mathrm{O}$ emissions from soils than $\mathrm{FN}$; the reason was that $\mathrm{BNF}$ was not considered to contribute to $\mathrm{N}_{2} \mathrm{O}$ emissions (Rochette and Janzen, 2005). In a study by Li et al. (2011) involving the direct measurement of $\mathrm{N}_{2} \mathrm{O}$ emissions from white clover and fertilizer N-based systems of dairy production (similar to those in the present study), annual emissions were $6.4 \mathrm{~kg}$ of $\mathrm{N}_{2} \mathrm{O}-\mathrm{N} / \mathrm{ha}$ from the $\mathrm{WC}$ system and $7.8 \mathrm{~kg}$ of $\mathrm{N}_{2} \mathrm{O}-\mathrm{N} /$ ha from the $\mathrm{FN}$ system. A clear reduction in $\mathrm{N}_{2} \mathrm{O}$ emissions was found when fertilizer $\mathrm{N}$ was replaced by BNF (Li et al., 2011), which was reflected in the difference in milk CF between the systems in this study.

Biological $\mathrm{N}$ fixation has been found to respond to changes in soil $\mathrm{N}$, which could mean greater efficiency of $\mathrm{N}$ utilization in WC-based pasture (Ledgard and Steele, 1992). However, N use efficiency (NUE) may differ little at the farm gate (i.e., $\mathrm{N}$ output/ $\mathrm{N}$ input). In grazing systems, NUE is closely related to optimization of the system inputs to the milk output (Fitzgerald et al., 2005) because urine during grazing (Rochen et al., 2004) and ammonia volatilization (Andrews et al., 2007 ) are critical to the $\mathrm{N}$ cycle and $\mathrm{N}_{2} \mathrm{O}$ emissions from the system. Under similar levels of total $\mathrm{N}$ input (including BNF), WC may have the same NUE as FN (Schils et al., 2000), whereas if FN has higher $\mathrm{N}$ input, it tends to have lower NUE than WC (Ledgard et al., 1999). This is in agreement with results of the current study and those of Humphreys et al. (2008, 2009), in which WC had lower total N input, higher NUE, and lower CF than FN during 2001 to 2002, and had similar total $\mathrm{N}$ input and NUE but $15 \%$ lower $\mathrm{CF}$ than $\mathrm{FN}$ during 2003 to 2006.

\section{Sensitivity at the Experimental System Scale}

The ratio sensitivity analysis revealed that to reverse the ranking of $\mathrm{WC}$ and $\mathrm{FN}$, changes to $\mathrm{EF}$ and assumptions had to be much greater than the uncertainty ranges found in the literature (Table 3). For example, the $\mathrm{EF}$ of enteric $\mathrm{CH}_{4}$ in $\mathrm{WC}$ would have to be increased by 23 to $55 \%$, but enteric $\mathrm{CH}_{4}$ from cows fed white clover was found to be lower (Pinares-Patiño et al., 2009) or similar (van Dorland et al., 2007) to that of cows fed grass. Because of the similar digestibility of the grazed pasture during the studies (Humphreys et al., 2008, 2009), the same EF of enteric $\mathrm{CH}_{4}$ was applied to both WC and FN. During earlier years, however, the pregrazing herbage of WC tended to have lower (although not always the lowest) OM digestibility (Humphreys et al., 2008). The required 23 to $55 \%$ increase would mean either higher gross energy content of clover or a larger methane conversion factor (IPCC, 2000), neither of which is likely (Andrews et al., 2007). On the other hand, the $\mathrm{EF}$ of $\mathrm{CH}_{4}$ from excretion deposition in $\mathrm{WC}$ 
would have to be increased by 6,116 to $14,920 \%$, but Jarvis et al. (1995) suggested a lower $\mathrm{CH}_{4}$ emission rate from dairy cows grazing grass or clover swards.

Other examples from the ratio sensitivity analysis support the conclusion that the difference between the management approaches was not caused by error. For instance, increasing the economic allocation in WC by 12 to $30 \%$ would result in no economic value for the slaughtered animals from WC, which is not tenable. Moreover, in Europe, permanent grasslands are believed to be carbon sinks, where higher $\mathrm{N}$ input will increase carbon sequestration (Soussana et al., 2007); therefore, it is not tenable that WC could lose 0.8 to $2.4 \mathrm{t}$ of $\mathrm{CO}_{2}$-eq/ha from oversowing of clover swards, which does not involve cultivation. There is no reason to believe that a significant difference in abiotic carbon storage between the 2 sward management approaches would arise in the timescale of these experiments. However, at the lower fertilization rate in FN (during 2001 and 2002), the difference in milk CF between WC and FN was less certain because of the large variation of $\mathrm{EF}$ for $\mathrm{N}_{2} \mathrm{O}$ emissions from soils, which was thought to follow a $\log$ normal distribution from 0.25 to $6 \%$, with a default of $1.25 \%$ (IPCC, 2000).

\section{CONCLUSIONS}

Life cycle assessment of pasture-based milk production from $\mathrm{WC}$ and $\mathrm{FN}$ systems indicated that the $\mathrm{CF}$ for WC was 11 to $23 \%$ lower (per $\mathrm{kg}$ of $\mathrm{ECM}$ ) than that for FN, which suggested that clover could be used to reduce the $\mathrm{CF}$ of milk. Ratio sensitivity analysis showed that enteric fermentation, $\mathrm{N}_{2} \mathrm{O}$ emissions from soils, soil carbon sequestration, and allocation could influence, but not reverse, the ranking of $\mathrm{WC}$ and $\mathrm{FN}$ systems, and that introducing clover reduced CF at the experimental system scale.

\section{ACKNOWLEDGMENTS}

This work was supported by the Department of Agriculture and Food Research Stimulus Fund Programme (RSF07-516) funded by the Irish Government National Development Plan, and funded in part by the European Research and Development Fund (ERDF) via Interreg IVB project O96D: Dairyman.

\section{REFERENCES}

Andrews, M., D. Scholefield, M. T. Abberton, B. A. McKenzie, S. Hodge, and J. A. Raven. 2007. Use of white clover as an alternative to nitrogen fertilizer for dairy pastures in nitrate vulnerable zones in the UK: Productivity, environmental impact and economic consideration. Ann. Appl. Biol. 151:11-23.
Anonymous. 2011. Fact sheet on Irish agriculture. Accessed July 3, 2012. http://www.agriculture.gov.ie/publications/2011/.

Basset-Mens, C., S. Ledgard, and M. Boyes. 2009. Eco-efficiency of intensification scenarios for milk production in New Zealand. Ecol. Econ. 68:1615-1625.

Björklund, A. E. 2002. Survey of approaches to improve reliability in LCA. Int. J. Life Cycle Assess. 7:64-72.

Casey, J. W., and N. M. Holden. 2005. Analysis of greenhouse gas emissions from the average Irish milk production system. Agric. Syst. 86:97-114.

Cederberg, C., and B. Mattsson. 2000. Life cycle assessment of milk production-A comparison of conventional and organic farming. J. Clean. Prod. 8:49-60.

Chadwick, D. R., B. F. Pain, and S. K. E. Brookman. 2000. Nitrous oxide and methane emissions following application of animal manures to grassland. J. Environ. Qual. 29:277-287.

Ecoinvent. 2011. Ecoinvent Data v2.2. Swiss Centre of Life Cycle Inventories, Zurich, Switzerland.

European Communities. 2010. Statutory Instrument No. 610. Good agricultural practice for protection of waters. The Stationery Office, Dublin, Ireland.

European Council. 1991. Directive 91/676/EEC of 12 December 1991 concerning the protection of waters against pollution caused by nitrates from agricultural sources. Accessed July 3, 2012. http:// eur-lex.europa.eu/LexUriServ/LexUriServ.do?uri=CELEX:31991 L0676:EN:HTML.

Fitzgerald, J. B., A. J. Brereton, and N. M. Holden. 2005. Dairy system simulation for assessing regional climate variation effects on management. Grass Forage Sci. 60:283-296.

Flysjö, A., M. Henriksson, C. Cederberg, S. Ledgard, and J.-E. Englund. 2011. The impact of various parameters on the carbon footprint of milk production in New Zealand and Sweden. Agric. Syst. 104:459-469.

Forster, P., V. Ramaswamy, P. Artaxo, T. Berntsen, R. Betts, D. W. Fahey, J. Haywood, J. Lean, D. C. Lowe, G. Myhre, J. Nganga, R. Prinn, G. Raga, M. Schulz, and R. van Dorland. 2007. Changes in atmospheric constituents and in radiative forcing. In Climate Change 2007: The Physical Science Basis. Contribution of working group I to the fourth assessment report of the Intergovernmental Panel on Climate Change. S. Solomon, D. Qin, M. Manning, Z. Chen, M. Marquis, K. B. Averyt, M. Tignor, and H. L. Miller, ed. Cambridge University Press, Cambridge, UK.

Gerber, P., T. Vellinga, C. Opio, B. Henderson, and H. Steinfeld. 2010. Greenhouse Gas Emissions from the Dairy Sector: A Life Cycle Assessment. Food and Agriculture Organization of the United Nations, Animal Production and Health Division, Rome.

Howley, M., B. Ó. Gallachóir, and E. Dennehy. 2008. Energy in Ireland 1990-2007. Sustainable Energy Ireland. Accessed July 3, 2012. http://www.seai.ie/Publications/Statistics_Publications/ Archived_Reports/.

Humphreys, J., I. A. Casey, and A. S. Laidlaw. 2009. Comparison of milk production from clover-based and fertilizer N-based grassland on a clay-loam soil under moist temperate climatic conditions. Ir. J. Agric. Food Res. 48:189-207.

Humphreys, J., E. Mihailescu, and I. A. Casey. 2012. An economic comparison of systems of dairy production based on $\mathrm{N}$-fertilized grass and grass-white clover grassland in a moist maritime environment. Grass Forage Sci. 67:519-525. http://dx.doi.org/10.1111/ j.1365-2494.2012.00871.x.

Humphreys, J., K. O'Connell, and I. A. Casey. 2008. Nitrogen flows and balances in four grassland-based systems of dairy production on a clay-loam soil in a moist temperate climate. Grass Forage Sci. $63: 467-480$

Husted, S. 1994. Seasonal variation in methane emission from stored slurry and solid manures. J. Environ. Qual. 23:585-592.

IPCC. 2000. IPCC Good Practice Guidance and Uncertainty Management in National Greenhouse Gas Inventories. Institute for Global Environmental Strategies, Kanagawa, Japan. Accessed July 3, 2012. http://www.ipcc-nggip.iges.or.jp/public/gp/english.

Ireland EPA (Environmental Protection Agency). 2012. Ireland's Greenhouse gas emissions in 2010. Environmental Protection 
Agency, Johnstown Castle Estate, Co. Wexford, Ireland. Accessed July 3rd, 2012 http://www.epa.ie/downloads/pubs/air/ airemissions/

ISO. 2006. Environmental management-Life cycle assessment requirements and guidelines. EN ISO 14044:2006. International Organization for Standardization (ISO), Geneva, Switzerland.

Jarvis, S. C., R. D. Lovell, and R. Panayides. 1995. Patterns of methane emission from excreta of grazing animals. Soil Biol. Biochem. 27:1581-1588.

Kramer, K. J., H. C. Moll, and S. Nonhebel. 1999. Total greenhouse gas emissions related to the Dutch crop production system. Agric. Ecosyst. Environ. 72:9-16.

Ledgard, S. F., J. W. Penno, and M. S. Sprosen. 1999. Nitrogen inputs and losses from clover/grass pastures grazed by dairy cows, as affected by nitrogen fertilizer application. J. Agric. Sci. (Camb.) 132:215-225.

Ledgard, S. F., R. L. M. Schils, J. Eriksen, and J. Luo. 2009. Environmental impacts of grazed clover/grass pastures. Ir. J. Agric. Food Res. 48:209-226.

Ledgard, S. F., and K. W. Steele. 1992. Biological nitrogen fixation in mixed legume/grass pastures. Plant Soil 141:137-153.

Li, D., G. Lanigan, and J. Humphreys. 2011. Measured and simulated nitrous oxide emissions from ryegrass- and ryegrass/white clover-based grasslands in a moist temperate climate. PLoS ONE 6:e26176.

McGettigan, M., P. Duffy, B. Hyde, E. Hanley, P. O'Brien, J. Ponzi, and K. Black. 2010. Ireland national inventory report 2010. Greenhouse gas emissions 1990-2008 reported to the United Nations Framework Convention on Climate Change. Environmental Protection Agency, Johnstown Castle Estate, Co. Wexford, Ireland. Accessed July 3, 2012. http://coe.epa.ie/ghg/nirs/NIR_2010_ IEv1.2.pdf.

O'Brien, D., L. Shalloo, C. Grainger, F. Buckley, B. Horan, and M. Wallace. 2010. The influence of strain of Holstein-Friesian cow and feeding system on greenhouse gas emissions from pastoral dairy farms. J. Dairy Sci. 93:3390-3402.

O'Mara, F. 2006. Climate change-Development of emission factors for the Irish cattle herd. Special report 2000-LS-5.1.1-M1. Environmental Protection Agency, Johnstown Castle, Co. Wexford, Ireland.

Pelletier, N., and P. Tyedmers. 2011. An ecological economic critique of the use of market information in life cycle assessment research. J. Indust. Ecol. 15:342-354.

Pinares-Patiño, C., G. Waghorn, R. Hegarty, and S. Hoskin. 2009. Effects of intensification of pastoral farming on greenhouse gas emissions in New Zealand. N. Z. Vet. J. 57:252-261.

PRé Consultants. 2011. SimaPro 7.3 LCA software. SimaPro/PRé Consultants, Amersfoort, the Netherlands.

Rochen, J. J., C. J. Doyle, J. M. Greef, A. Hopkins, M. Molle, M. Sitzia, D. Scholefield, and C. J. Smith. 2004. Grazing legumes in Europe: A review of their status, management, benefits, research needs and future prospects. Grass Forage Sci. 59:197-214.

Rochette, P., and H. H. Janzen. 2005. Towards a revised coefficient for estimating $\mathrm{N}_{2} \mathrm{O}$ emissions from legumes. Nutr. Cycl. Agroecosyst. 73:171-179.
Rotz, C. A., F. Montes, and D. S. Chianese. 2010. The carbon footprint of dairy production systems through partial life cycle assessment. J. Dairy Sci. 93:1266-1282.

Schau, E. M., and A. M. Fet. 2007. LCA studies of food products as background for environmental product declarations. Int. J. Life Cycle Assess. 13:255-264.

Schils, R. L. M., T. J. Boxem, C. J. Jagtenberg, and M. C. Verboon. 2000. The performance of a white clover based dairy system in comparison with a grass/fertilizer-N system. II. Animal production, economics and environment. Neth. J. Agric. Sci. 48:305-318.

Schils, R. L. M., A. Verhagen, H. F. M. Aarts, P. J. Kuikman, and L. B. J. Šebek. 2006. Effect of improved nitrogen management on greenhouse gas emissions from intensive dairy systems in the Netherlands. Glob. Change Biol. 12:382-391.

Schils, R. L. M., A. Verhagen, H. F. M. Aarts, and L. B. J. Šebek. 2005. A farm level approach to define successful mitigation strategies for GHG emissions from ruminant livestock systems. Nutr. Cycl. Agroecosyst. 712:163-175.

Shalloo, L., P. Dillon, M. Rath, and M. Wallace. 2004. Description and validation of the Moorepark Dairy System Model. J. Dairy Sci. 87:1945-1959.

Sjaunja, L. O., L. Baevre, L. Junkkarinen, J. Pedersen, and J. Setala. 1990. A Nordic proposal for an energy corrected milk (ECM) formula. Page 192 in 27th session of the International Commission for Breeding and Productivity of Milk Animals, Paris, France. EAAP Publication No 50. Centre for Agricultural Publishing and Documentation, Wageningen, the Netherlands.

Soussana, J. F., V. Allard, K. Pilegaard, P. Ambus, C. Amman, C. Campbell, E. Ceschia, J. Clifton-Brown, S. Czobel, R. Domingues, C. Flechard, J. Fuhrer, A. Hensen, L. Horvath, M. Jones, G. Kasper, C. Martin, Z. Nagy, A. Neftel, A. Raschi, S. Baronti, R. M. Rees, U. Skiba, P. Stefani, G. Manca, M. Sutton, Z. Tuba, and R. Valentini. 2007. Full accounting of the greenhouse gas $\left(\mathrm{CO}_{2}\right.$, $\mathrm{N}_{2} \mathrm{O}, \mathrm{CH}_{4}$ ) budget of nine European grassland sites. Agric. Ecosyst. Environ. 121:121-134.

Steinfeld, H., P. Gerber, T. Wassenaar, V. Castel, M. Rosales, and C. de Haan. 2006. Livestock's Long Shadow: Environmental Issues and Options. Food and Agriculture Organization of the United Nations, Animal Production and Health Division, Rome, Italy.

Thomassen, M. A., K. J. van Calker, M. C. J. Smits, G. L. Iepema, and I. J. M. de Boer. 2008. Life cycle assessment of conventional and organic milk production in the Netherlands. Agric. Syst. 96:95-107.

van Dorland, H. A., H.-R. Wettstein, H. Leuenberger, and M. Kreuzer. 2007. Effect of supplementation of fresh and ensiled clovers to ryegrass on nitrogen loss and methane emission of dairy cows. Livest. Sci. 111:57-69.

Yan, M.-J., J. Humphreys, and N. M. Holden. 2011. An evaluation of life cycle assessment of European milk production. J. Environ. Manage. 92:372-379. 